\section{References}

Altchek, A. (1961). Fournal of the American Medical Association, 175, 791. Beller, F. K. (1964). Cited by McKay, De Bacalao, and Sedlis (1964). Bonnar, J., Davidson, J. F., Pidgeon, C. F., McNicol, G. P., and Douglas, A. S. (1969a). British Medical fournal, 3, 137.

Bonnar, J., McNicol, G. P., and Douglas, A. S. (1969b). British Medical Fournal, 3, 387.

Brain, M. C., Kuah, K.-B., and Dixon, H. G. (1967). Fournal of Obstetrics and Gynaecology of the British Commonwealth, 74, 702.

Breckenridge, R. T., and Ratnoff, O. D. (1962). Blood, 20, 137.

Breckenridge, R. T., and Ratnoff, O. D. (1962). Blood, 20, 137.

Fantl, P., and Simon, S. E. (1948). Australian fournal of Experimental Biology and Medical Science, 26, 521 .

Fletcher, A. P., Biederman, O., Moore, D., Alkjaersig, N., and Sherry, S. (1963). Transactions of the Association of American Physicists, 76, 280. Henderson, A. H., Pugsley, D. J., and Thomas, D. P. (1970). British Medical fournal, 3, 545 .

Hjort, P. F., and Rapaport, S. I. (1965). Annual Review of Medicine, 16, 135. Jeffcoate, T. N. A. (1966). Proceedings of the Royal Society of Medicine, 59, 397.

McKay, D. G. (1965). In Disseminated Intravascular Coagulation. New York, Hoeber.

McKay, D. G., De Bacalao, E. B., and Sedlis, A. (1964). American fournal of Obstetrics and Gynecology, 90, 1315.
McKay, D. G., Merrill, S. J., Weiner, A. E., Hertig, A. T., and Reid, D. E. (1953). American fournal of Obstetrics and Gynecology, 66, 507.

McNicol, G. P., Barakat, A. A., and Douglas, A. S. (1965). Scottish Medical Fournal, 10, 189.

McNicol, G. P., and Douglas, A. S. (1964). In Recent Advances in Clinical Pathology, Series 4, ed. S. C. Dyke, p. 187. London, Churchill.

Morris, R. H., Vassalli, P., Beller, F. K., and McCluskey, R. T. (1964). Obstetrics and Gynecology, 24, 32.

Nielsen, N. C. (1969). Acta Obstetricia et Gynecologica Scandinavica, 48, 529 Niewiarowski, F. (1968). In XII Congress of International Society of Haematologists, p. 330. New York, Plenary Sessions.

Page, E. W., Fulton, L. D., and Glendening, M. B. (1951). American fournal of Obstetrics and Gynecology, 61, 1116.

Pollak, V. E., and Nettles, J. B. (1960). American fournal of Obstetrics and Gynecology, 79, 866 .

Ratnoff, O. D., and Menzie, C. (1965). In Blood Coagulation, Hemorrhagc and Thrombosis, ed. L. M. Tocantins and L. A. Kazal, p. 224. New York, Grune and Stratton.

Schneider, C. L. (1947). American fournal of Physiology, 149, 123.

Vassalli, P., and McCluskey, R. T. (1965). American fournal of Medicine, $39,179$.

Ward, C. V., and MacArthur, J. L. (1948). American fournal of Obstetrics and Gynecology, 55, 600.

Wardle, E. N., and Menon, I. S. (1969). British Medical fournal, 2, 625.

\title{
Serum Gastrin in Chronic Gastritis
}

\author{
M. G. KORMAN, R. G. STRICKLAND, J. HANSKY
}

British Medical fournal, 1971, 2, 16-18

\section{Summary}

Fasting gastrin levels in serum were measured in 49 patients with different types of chronic gastritis and in matched controls. In 15 patients with established pernicious anaemia the mean ( \pm S.E. of mean) level of gastrin was greatly raised $(699$ $\pm 99 \mathrm{pg} / \mathrm{ml})$. In 17 patients with chronic atrophic gastritis, seropositive for parietal cell antibody but with adequate vitamin-B $B_{12}$ absorption, the level was also raised (476 \pm 74 $\mathrm{pg} / \mathrm{ml}$ ). By contrast, in "simple" atrophic gastritis seronegative for parietal cell antibody the gastrin levels were significantly lower for both diffuse atrophic gastritis $(129 \pm 31 \mathrm{pg} / \mathrm{ml})$ and multifocal gastritis $(14 \pm 4 \mathrm{pg} / \mathrm{ml})$. These levels were similar to those in the controls $(46 \pm 7 \mathrm{pg} / \mathrm{ml})$.

The mechanism of the raised gastrin levels remains uncertain, but neither achlorhydria nor in vivo action of the parietal cell antibody wholly accounted for the hypergastrinaemia.

We conclude that hypergastrinaemia is characteristic of gastritis associated with autoimmune reactions to gastric antigens and pernicious anaemia and that a raised serum gastrin is a useful marker of the type of gastritis that tends to progress to the gastric lesion of pernicious anaemia. The findings suggest that this type of gastritis is an essentially different disease from "simple" atrophic gastritis, and the differences in gastrin levels may be due to sparing of the antral mucosa in the autoimmune type but not in "simple" gastritis.

\section{Introduction}

The isolation, purification, and synthesis of human gastrin (Gregory, 1966) led to the development of a radioimmuno-

\footnotetext{
Monash University Department of Medicine, Prince Henry's Hospital, Melbourne, Australia

M. G. KORMAN, M.R.A.C.P., Research Fellow

J. HANSKY, M.R.A.C.P., Senior Lecturer

Clinical Research Unit, Walter and Eliza Hall Institute of Medical Research, Melbourne, Australia

R. G. STRICKLAND, M.R.A.C.P., Assistant Physician
}

assay to measure gastrin levels in blood (McGuigan 1968a). Gastrin levels are raised in the Zollinger-Ellison syndrome (McGuigan and Trudeau, 1968; Hansky and Cain, 1969) and in Addisonian pernicious anaemia (McGuigan and Trudeau, 1970; Yalow and Berson, 1970). Lack of acid inhibition of gastrin release is the suggested explanation of the hypergastrinaemia of pernicious anaemia (Yalow and Berson, 1970) This study examines the relationship of serum gastrin levels to the type of gastritis, the presence or absence of achlorhydria, and the presence or absence of gastric autoantibodies in patients with gastritis.

\section{Patients and Methods}

Forty-nine patients with chronic gastritis and basal achlorhydria and 49 control subjects were studied. The patients were divided into four groups on the basis of gastric mucosal histology, vitamin- $\mathrm{B}_{12}$ absorption by Schilling test, and tests for parietal cell antibody (see Table).

Vitamin- $B_{12}$ absorption was estimated by the Schilling tes with $1 \mu \mathrm{g}$ of ${ }^{5 /} \mathrm{Co}$ vitamin $\mathbf{B}_{1,2}$, flushing dose of $1 \mathrm{mg}$ of unlabelled vitamin $B_{12}$ two hours later, and a 48-hour collec tion of urine; an excretion of less than $5 \%$ of the administered dose was taken to be diagnostic of pernicious anaemia When appropriate the test was repeated with $1,000 \mathrm{ng}$ units of hog intrinsic factor (WES 818 Lederle).

Acid secretion was assessed by using the criteria of Kay (1953) following a maximal dose of either ametazole hydrochloride (betazole hydrochloride, Histalog), $1.5 \mathrm{mg} / \mathrm{kg}$ body weight, or histamine acid phosphate, $0.04 \mathrm{mg} / \mathrm{kg}$ body weight Results were expressed in total $\mathrm{mEq}$ per hour basally and after stimulation. Basal achlorhydria refers to gastric juice with no titratable acidity to $\mathrm{pH}$ 7.4. Histamine-fast or Histalog-fast achlorhydria refers to failure to change $\mathrm{pH}$ by more than one unit after stimulation and the absence of titratable acidity to $\mathrm{pH} 7 \cdot 4$. Total achlorhydria refers to the combination of basal and post-stimulation achlorhydria.

Gastric mucosal biopsy specimens were obtained from the body or fundus of each patient by means of Wood's tubc (Wood et al., 1949). The average number of biopsy specimens from each patient was five (range 2-17). The specimens were classified, according to te Velde et al. (1966), into chronic 
Gastric Secretion, Mucosal Histology, Autoantibodies, and Mean Serum Gastrin in 49 Patients with Chronic Gastritis

\begin{tabular}{|c|c|c|c|c|c|c|c|c|c|c|}
\hline \multirow{2}{*}{ Group } & \multirow{2}{*}{ No. } & \multirow{2}{*}{$\begin{array}{l}\text { Basal } \\
\text { Achlorhydria }\end{array}$} & \multicolumn{2}{|c|}{ Acid Response to Stimulation } & \multicolumn{2}{|c|}{ Gastric Autoantibodies } & \multicolumn{3}{|c|}{ Gastric Mucosal Histology } & \multirow{2}{*}{$\begin{array}{l}\text { Serum Gastrin } \\
\text { (pg/ml) (Mean } \pm \\
\text { S.E. of Mean) }\end{array}$} \\
\hline & & & Achlorhydria & Acid Secretion & Parietal Cell & Intrinsic Factor & C.M.G. & D.A.G. & G.A. & \\
\hline $\begin{array}{l}1 \\
2 \\
3 \\
4\end{array}$ & $\begin{array}{r}15 \\
17 \\
11 \\
6\end{array}$ & $\begin{array}{r}15 \\
17 \\
11 \\
6\end{array}$ & $\begin{array}{r}15 \\
16 \\
11 \\
0\end{array}$ & $\begin{array}{l}0 \\
1 \\
0 \\
6\end{array}$ & $\begin{array}{r}14 \\
17 \\
0 \\
0\end{array}$ & $\begin{array}{l}7 \\
7 \\
0 \\
0\end{array}$ & $\begin{array}{l}0 \\
1 \\
0 \\
6\end{array}$ & $\begin{array}{r}9 \\
16 \\
9 \\
0\end{array}$ & $\begin{array}{l}6 \\
0 \\
2 \\
0\end{array}$ & $\begin{array}{c}699 \pm 99 \\
476 \pm 74 \\
129 \pm 31 \\
14 \pm 4\end{array}$ \\
\hline
\end{tabular}

C.M.G. = Chronic Multifocal Gastritis. D.A.G. = Diffuse Atrophic Gastritis. G.A. = Gastric Atrophy.

multifocal atrophic gastritis, chronic diffuse atrophic gastritis, or gastric atrophy.

Parietal cell antibody was detected by indirect immunofluorescence with rat stomach as antigen (De Boer et al., 1965). Circulating type I or "blocking" antibody to intrinsic factor was detected by the charcoal assay as modified by Ungar (1967).

Group 1: Pernicious Anaemia (15 patients).-The mean age was 63 years and the sex ratio (F:M) 4:1. All had total achlorhydria. Histologically nine patients had diffuse atrophic gastritis and six had gastric atrophy. In all cases the Schilling test results were less than $5 \%$, correctable by hog intrinsic factor. Parietal cell antibody was present in 14 patients and antibody to intrinsic factor in seven.

Group 2: Atrophic Gastritis Seropositive for Parietal Cell Antibody (17 patients).-The mean age was 56 years and sex ratio 4.6:1. Five patients gave a family history of pernicious anaemia and 14 had a disease believed to be associated with pernicious anaemia, including diabetes mellitus (7), hypothyroidism (3), and hyperthyroidism (4). Sixteen had total achlorhydria and one had basal achlorhydria and secreted 3.4 $\mathrm{mEq}$ of acid after stimulation. The gastric biopsies showed diffuse alrophic gastritis in all except one patient who had chronic multifocal gastritis. The results of the Schilling test ranged from 7 to $22 \%$, mean $13 \%$. Antibody to intrinsic factor was present in seven patients.

Group 3: Atrophic Gastritis Seronegative for Parietal Cell Antibody (11 patients).- The mean age was 69 years and the sex ratio $3: 1$. All had total achlorhydria. Histologically nine patients had diffuse atrophic gastritis and two had gastric atrophy. Vitamin- $B_{1:}$ absorption was normal in all patients (range $9-23 \%$, mean $15 \%$ ). Tests for antibodies to parietal cells and intrinsic factor were negative.

Group 4: Multifocal Gastritis Seronegative for Parietal Cell Antibody (6 patients).- The mean age was 66 years and the sex ratio 5:1. All had basal achlorhydria but secreted some acid after stimulation, ranging from 1.2 to $8 \mathrm{mEq} /$ hour. Vitamin- $B_{12}$ absorption was normal in all patients (range 11$37 \%$, mean $24 \%$ ). Tests for antibodies to parietal cells and intrinsic factor were negative.

Group 5: Controls (49 patients).-These were patients in hospital without known gastrointestinal disease matched for age and sex with the patients studied.

\section{SERUM GASTRIN LEVELS}

In all patients fasting serum gastrin levels were measured by radioimmunoassay (Hansky and Cain, 1969), without previous knowledge of gastric structure, function, or serology. The results were cxpressed in $\mathrm{pg} / \mathrm{ml}$ serum.

\section{STATISTICS}

Statistical analysis was by Student's $t$ test for unpaired data, comparing group means. Calculations were made on an Olivetti Program Computer using standard formulae; $\mathrm{P}<0.05$ was taken as a significant difference between group means.

\section{Results}

Mean gastrin levels, acid secretory capacity, mucosal histology, and gastric autoantibodies are shown in the Table. The range of gastrin levels in Groups 1 to 4 is shown in the Chart related both to mucosal histology and to levels for hospital controls.

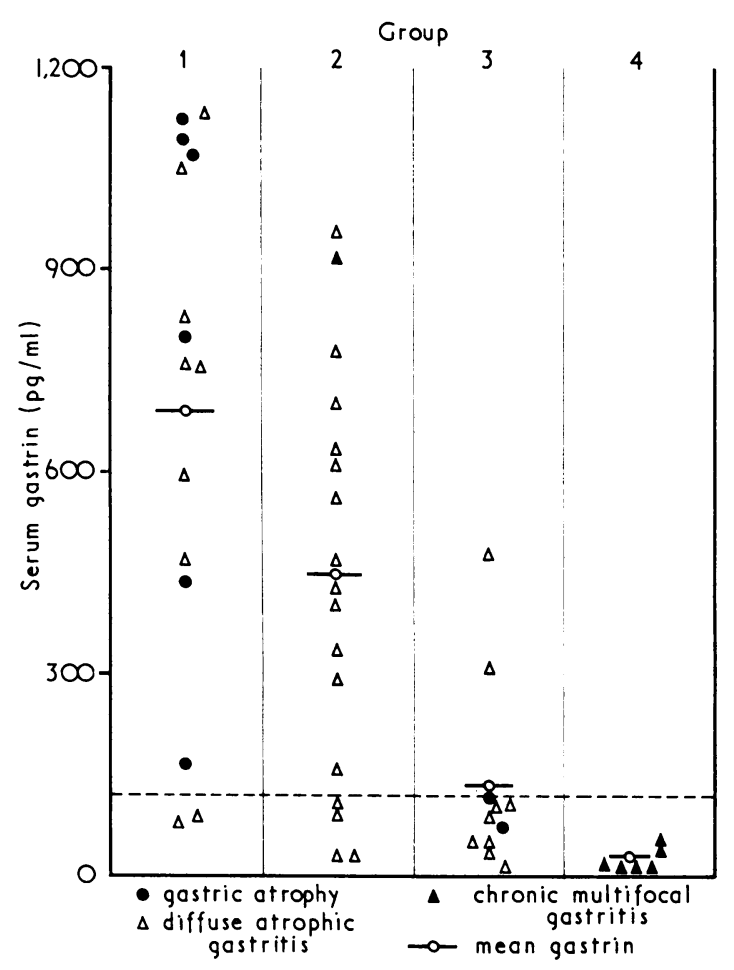

Fasting serum gastrin in groups 1 to 4 shown in relation to gastric mucosal histology. The dotted line represents the upper limit of the normal range (2 S.D. above mean level established for 49 controls).

The mean ( \pm S.E. of mean) fasting serum gastrin level was $699 \pm 99 \mathrm{pg} / \mathrm{ml}$ for Group 1, $476 \pm 74 \mathrm{pg} / \mathrm{ml}$ for Group 2, $129 \pm 31 \mathrm{pg} / \mathrm{ml}$ for Group 3, and $14 \pm 4 \mathrm{pg} / \mathrm{ml}$ for Group 4 . The level was $46 \pm 7 \mathrm{pg} / \mathrm{ml}$ for the controls. The difference bctween mean gastrin levels in Groups 1 and 2 was not significant, but the levels for both these groups were significantly higher than those for Groups 3 and 4 and the controls $(\mathrm{P}<0.001)$.

In Group 1 two patients had gastrin levels within the normal range. Parietal cell antibody was present in both patients. Hypergastrinaemia was independent of the presence of antibody to intrinsic factor. The patients with gastric atrophy werc evenly distributed throughout the range of gastrin levels (sce Chart).

For Group 2 the range of gastrin levels was equivalent to that for established pernicious anaemia. Though four patients had normal gastrin levels, their gastric structure and function did not differ from that of the remainder of the group. The serum gastrin level in the one patient who secreted some acid 
was slightly raised $(160 \mathrm{pg} / \mathrm{ml})$, while it was high $(940 \mathrm{pg} / \mathrm{ml})$ in the one patient having chronic multifocal gastritis. Raised gastrin levels were present in four of the five patients who gave a family history of pernicious anaemia and in 11 of the 14 patients with associated diabetes mellitus or thyroid disease. Again hypergastrinaemia was independent of the presence of antibody to intrinsic factor.

For Group 3 the mean gastrin level was significantly higher than that for controls $(P<0.025)$. The Chart, however, shows that only two patients in this group had hypergastrinaemia, and one of these had thyroiditis and gave a family history of pernicious anaemia. Again there was no relationship between the types of gastric mucosal abnormality and gastrin levels.

In Group 4 all patients had gastrin levels below $35 \mathrm{pg} / \mathrm{ml}$. These were in the low part of the range obtained for the control patients.

\section{Discussion}

This study confirms that most patients with Addisonian pernicious anaemia have greatly raised serum gastrin levels. The mechanism of this rise in pernicious anaemia has been attributed to continued release of the hormone from cells in the gastric antrum because of a persistently high intraluminal $\mathrm{pH}$ (McGuigan and Trudeau, 1970). Gastrin release is inhibited when the $\mathrm{pH}$ in the region of the antrum falls below 3 (Dragstedt, 1969), and the recent finding by Yalow and Berson (1970) of pronounced reduction in serum gastrin levels when patients with pernicious anaemia ingest $0.1 \mathrm{~N} \mathrm{HCl}$ supports this hypothesis.

\section{MECHANISM OF HYPERGASTRINAEMIA}

This study investigated two possible mechanisms for hypergastrinaemia in pernicious anaemia: the presence of achlorhydria, and inhibition of gastrin action in vivo by the parietal cell antibody.

Presence of Achlorhydria.-Our results showed that fasting gastrin levels are normal in occasional patients with pernicious anaemia or parietal-cell-antibody-positive gastritis and in most patients with parietal-cell-antibody-negative atrophic gastritis, all with total achlorhydria. In addition, patients with parietal-cell-antibody-negative chronic multifocal gastritis (Group 4) had low normal gastrin levels in the basal state despite basal achlorhydria. Hence the loss of acid inhibition of gastrin release cannot wholly account for hypergastrinaemia.

Parietal Cell Antibody.-The significantly higher gastrin levels observed in patients with gastritis and parietal cell antibody, compared with those without parietal cell antibody, require a consideration of the role of the antibody in the causation of hypergastrinaemia. The effector site of gastrin action in the parietal cell is not known, but in vivo binding of parietal cell antibody could interfere with this effector site and lead to a build up of circulating levels of the hormone. Nevertheless, the correlation between the presence of circulating parietal cell antibody and hypergastrinaemia, though close, was not exact, and raised levels were observed in two patients in whom the antibody was not detected.

Since the presence of achlorhydria or in vivo action of parietal cell antibody does not wholly account for the hypergastrinaemia alternative explanations should be considered. Proliferation of enterochromaffin-like cells in the mucosa of the body of the stomach in pernicious anaemia (Rubin, 1969) may be important. In the normal stomach these cells are largely confined to the antral mucosa and are believed to be the site of gastrin production (McGuigan, 1968b). The hypergastrinaemia may be due to increased production consequent on this proliferation.

\section{ROLE OF GASTRIC ANTRUM}

In our study the serum gastrin was independent of the mucosal appearances in the body or fundus of the stomach, and it is likely that the extent of gastritis is of importance in determining levels of gastrin. Magnus and Ungley (1938) established that the mucosal atrophy in pernicious anaemia was mainly confined to the body and fundus of the stomach. With the additional factor of a normal antral mucosa in the presence of achlorhydria hypergastrinaemia could develop.

The normal gastrin levels found in some patients with pernicious anaemia or parietal-cell-antibody-positive gastritis and in most patients with parietal-cell-antibody-negative gastritis may indicate an extension of gastritis to the antrum. With many gastrin-producing cells destroyed in the atrophic process gastrin levels would not be raised despite the lack of inhibition of gastrin release associated with achlorhydria.

\section{IMPLICATIONS OF GASTRIN LEVELS IN ATROPHIC GASTRITIS}

The present finding of high serum gastrin levels in pernicious anaemia and parietal-cell-antibody-positive atrophic gastritis but normal levels in parietal-cell-antibody-negative gastritis suggests that the gastritis associated with the presence of parietal cell antibody is an essentially different disease from that known as "simple" gastritis, whether diffuse or multifocal. The latter "normogastrinaemic" type is not associated with the presence of parietal cell antibody and only very rarely with malabsorption of vitamin $B_{12}$ and pernicious anaemia. We anticipate that serum gastrin levels will prove useful in patients with gastritis and total achlorhydria, as a further marker of the type of gastritis which determines the eventual development of the gastric lesion of pernicious anaemia.

This work was supported by the National Health and Medical Research Council of Australia. We thank Miss Claire Soveny for expert technical help with the gastrin immunoassay, Sister I. Langford for help with the collection of blood and the gastric function tests, Dr. B. Ungar for the Schilling tests, and Dr. S. Whittingham for performing the tests for parietal cell antibody. Dr. F. I. R. Martin gave permission to study three patients under his care.

Address requests for reprints to Dr. M. G. Korman, Monash University Department of Medicine, Prince Henry's Hospital, St Kilda Road, Melbourne 3004, Australia.

\section{References}

De Boer, W. G. R. M., Nairn, R. G., and Maxwell, A. J. (1965). Australian fournal of Clinical Pathology, 18, 456

Dragstedt, L. R. (1969). American fournal of Surgery, 117, 143.

Gregory, R. A. (1966). Gastroenterology, 51, 953.

Hansky, J., and Cain, M. D. (1969). Lancet, 2, 1388.

Kay, A. W. (1953). British Medical fournal, 2, 77.

McGuigan, J. E. (1968a). Gastroenterology, 54, 1005.

McGuigan, J. E. (1968a). Gastroenterology, 54, 1005. McGuigan, J. E., and Trudeau, W. L. (1968). New England fournal of

McGuigan, J. E., and Trudeau, W. L. (1970). New England fournal of Medicine, 282, 358.

Magnus, H. A., and Ungley, C. C. (1938). Lancet, 1, 420.

Rubin, W. (1969). Gastroenterology, 57, 641 .

te Velde, K., Hoedemaeker, P. J., Anders, G. J. P. A., Arends, A., and Nieweg, H. O. (1966). Gastroenterology, 51, 138.

Ungar, B. (1967). Australian fournal of Experimental Biology and Medical Science, 45, 317.

Wood, I. J., Doig, R. K., Motteram, R., and Hughes, A. (1949). Lancet, 1,

Yalow, R. S., and Berson, S. A. (1970). Gastroenterology, 58, 1. 